\title{
Development of Mobile Learning in Learning Media to Improve Digital Literacy and Student Learning Outcomes in Physics Subjects: Systematic Literature Review
}

\author{
Rafi Eka Wijaya ${ }^{1}$, Mustaji ${ }^{2}$, Hari Sugiharto ${ }^{3}$ \\ ${ }^{1,2,3}$ Educational Technology Study Program, State University of Surabaya, Indonesia \\ rafiekawijaya@gmail.com
}

\section{Abstract}

This study aims to analyze the development of mobile learning in learning media to improve digital literacy and student learning outcomes in physics subjects. The method used in writing this systematic literature review is to search for the literature using a database on Google Scholar. The results of the study show that the use of mobile learning in student learning can be used as a learning support tool, media and learning resource and can be applied at the student level. The benefits of using mobile learning in learning are that it can facilitate the teaching and learning process both in the classroom and outside the classroom, attract students' attention and can generate enthusiasm and motivation in learning so that the material being delivered can be conveyed properly and can be understood by students, besides another benefit of using mobile learning is that it can support students towards independent learning. The development of mobile learning as a learning medium has been carried out by several researchers, who develop mobile learning. The results of the development carried out indicate that the media developed is more likely to focus on the teaching material only. Mobile learning developed is focused as a means of practicing working on questions that can provide various types of questions that are varied and challenging.
Keywords

learning media; mobile learning; digital literacy; learning outcomes

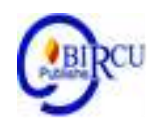

\section{Introduction}

Since the last decade, the character of education has become an important issue. This problem is caused by the emergence of components of the nation's behavior phenomenon, especially the younger generation who tend to prioritize hedonistic traits that are not in accordance with the religious principles of social principles, legal rules and norms that apply in Indonesian society (Sudrajat, 2011). In the context of nationality, this behavior shows the fading values of the national spirit among the younger generation which are increasingly evident. The act of not paying attention to the national symbol, not memorizing Pancasila, disliking and even not knowing the national anthem, not recognizing national heroes, not being proud and not knowing the nation's culture, would be even worse. (Pradana et al, 2020)

Education is a lifelong necessity (Sudarsana, 2016). Every human being needs education wherever he is and throughout his life. Education is very important which means without education, humans will difficult to develop and cause humans to be very left behind (Karsidi, 2017). 
One of the challenges of education today is creating skills, according to (Suarsana, 2013) including information and communication technology literacy skills, critical thinking skills, problem solving skills, effective communication skills and collaboration skills. These skills, according to the United Nations (UN) is characteristic of today's global society, namely a knowledge-based society. (Chaeruman, 2010).

The way to produce a quality learning process, there are several aspects that also affect, namely: teaching, the use of interesting and varied learning methods from student learning behavior, conducive learning conditions and atmosphere as well as the use of innovative learning media in supporting the teaching and learning process itself (Astuti \& Bhakti, 2018). Learning media is one of the elements that plays an important role in the learning process in addition to the methods used in teaching.

According to (Hartawan et al., 2014) in physics subjects during the teaching process in the classroom, educators (teachers) tend to be less creative and innovative in applying learning media when teaching. So far, the learning media that is often used in delivering material is textbooks, while using PowerPoint is still rarely applied. Even though several media have been used to support the learning process, student learning outcomes are still relatively low. One of the factors is the lack of student motivation in studying physics which is considered as a boring subject (Jamilah et al., 2020) and become a scary thing, thus affecting students' learning outcomes.

Various alternatives to improve the weakness of the application of physics learning must be done by using innovative learning media. With the existence of learning media that are in accordance with the needs and characteristics of students, it is hoped that learning will take place effectively and efficiently (Hartini et al., 2019).

Based on the results of interviews and observations with teachers that have been carried out by (Hartini et al., 2019) said that teachers rarely use learning media, especially those based on Information and Technology (IT) learning media such as e-learning-based learning media. This occurs as a result of the lack of available facilities and infrastructure, especially related to Information and Technology (IT)-based learning media, and the lack of understanding and skills of teachers to design Information and Technology (IT)-based learning media.

The development of technology and information in modern times is very influential for daily life for all circles, both students and students. One of them is the use of smartphones. The level of development of smartphone devices which is getting higher and relatively cheaper is a factor supporting the increasing number of smartphone users. The digital marketing research institute Emarketer estimates that in 2018 the number of active smartphone users in Indonesia will reach more than 100 million people. With such a large number, Indonesia will become the country with the fourth largest active smartphone users in the world after China, India and America (Wahyudi, 2015).

The more students who own and use mobile devices, the greater the opportunities for using technology devices in education. Learning media that utilizes cell phone technology define as mobile learning. Mobile learning is an alternative for developing learning media. The presence of mobile learning is intended as a complement to learning and provides opportunities for students to learn material that is less mastered anywhere and anytime (Fatimah, 2014). Many students still use laptops or some even use manuals to support learning at school. Using a laptop as a learning medium will make it difficult for students to carry the device because it is heavy and seems troublesome.

Seeing this potential, the development of learning media by utilizing cell phones is to create mobile learning that is intended for all cellular phones with the Android platform. The reason is because the Android operating system is transformed into a system that is most 
widely used on smartphones. However, most teachers rarely use learning media in the process of teaching and learning activities in the classroom. Teachers experience problems and difficulties in preparing learning media with technology, as a result, teachers only explain the material with PowerPoint slides.

Physical material is a material related to daily life, so teachers are required to be able to explain the concept into real form. Pressure material is one of the materials that seems abstract to students, many students who have not been able to transfer the material in concrete form. So in the end many students are lazy to learn physics because there are too many formulas for the application. If only by using the lecture method will make the students become bored and bored. There must be other methods that teachers do to change the mindset of students.

Based on this explanation, many studies have used m-learning learning media to determine the effect and effectiveness of m-learning and others when it is applied. So this study was conducted to determine whether the use of m-learning learning media is effective in improving student learning outcomes from several existing studies. So the teacher can consider using it.

\section{Research Methods}

\subsection{Search Strategy}

The method used in writing literature review is to search for literature that is done using a database such as Google Scholar. At the beginning of the search with keywords: "Mobile learning media", "Digital Literacy" and "Student Learning Outcomes", a total of 66,600 articles were obtained, after being screened by looking at the inclusion criteria obtained 14 articles from the time span of 2014 to 2021.

\subsection{Inclusion Criteria}

The following inclusion criteria were used for the selection of studies for the literature review, namely:

Research related to "Mobile learning Media", "Digital Literacy" and "Learning Outcomes of Students"

\subsection{Exclusion Criteria}

a. Non-original publications such as abstracts only, for articles with unclear titles and abstracts will be checked and evaluated from all publications taken.

b. Articles whose title does not match the search topic.

c. Indonesian language articles. 


\section{Result and Discussion}

The results of this literature review identified 13 articles that met the criteria, these results can be seen in the table below.

Table 1. Characteristic Study

\begin{tabular}{|c|c|c|c|c|}
\hline No & Researcher & Title & Methods & Result \\
\hline 1 & $\begin{array}{l}\text { (Gunawan, } \\
\text { 2014) }\end{array}$ & $\begin{array}{lr}\text { Physics } & \text { Mobile } \\
\text { learning } & \text { Application } \\
\text { as a } & \text { Supporting } \\
\text { Learning Media }\end{array}$ & $\begin{array}{l}\text { (R\&D)Develo } \\
\text { pment }\end{array}$ & $\begin{array}{l}\text { learning media in the form of mobile } \\
\text { learning can be used as a supporting } \\
\text { learning media in physics lessons for } \\
\text { high school students }\end{array}$ \\
\hline 2 & $\begin{array}{l}\text { (Handayani } \\
\& \\
\text { Suharyanto, } \\
\text { 2016) }\end{array}$ & $\begin{array}{l}\text { Development } \\
\text { Android-Based } \\
\text { Mobile Learning as } \\
\text { a Learning } \\
\text { on Static Flia } \\
\text { Materials } \\
\text { Increase Interest and } \\
\text { Learning Outcomes } \\
\text { in the Cognitive } \\
\text { Domain of Students }\end{array}$ & $\begin{array}{l}\text { Development } \\
\text { (R\&D) with a } \\
\text { 4-D model, } \\
\text { namely define, } \\
\text { design, } \\
\text { develop, and } \\
\text { disseminate }\end{array}$ & $\begin{array}{l}\text { The android-based mobile } \\
\text { learning media that was developed is } \\
\text { feasible to use with a very good } \\
\text { category which can be seen from the } \\
\text { average CVI score of the validator } \\
\text { assessment which is } 0.98 \text {, the results } \\
\text { of student responses with an average } \\
\text { CVI value of } 0.9 \text { in the very good } \\
\text { category. (2) An increase in student } \\
\text { learning outcomes in class XI IPA } 1 \\
\text { has a standard gain value of } 0.66 \text { in } \\
\text { the medium category, and (3) an } \\
\text { increase in student interest in } \\
\text { learning in class XI IPA } 1 \text { has a } \\
\text { standard gain value of } 0.66 \text { in the } \\
\text { medium category. }\end{array}$ \\
\hline 3 & $\begin{array}{l}\text { (Paramita et } \\
\text { al., 2017) }\end{array}$ & $\begin{array}{l}\text { Development of } \\
\text { Learning Media in } \\
\text { the Form of } \\
\text { Animation Based on } \\
\text { Mobile learning (M- } \\
\text { Learning) on } \\
\text { Straight Motion } \\
\text { Materials in Junior } \\
\text { High Schools }\end{array}$ & $\begin{array}{l}\text { ADDIE } \\
\text { development } \\
\text { model }\end{array}$ & $\begin{array}{l}\text { the results of the analysis of learning } \\
\text { media needs found that only } 30 \% \\
\text { teachers use the help of animated } \\
\text { visual media and no teacher has } \\
\text { implemented mobile learning yet in } \\
\text { learning, then the development of } \\
\text { mobile-based animation learning } \\
\text { media learning on straight motion } \\
\text { material can be used as teaching } \\
\text { material to support students. This } \\
\text { learning media contains material, } \\
\text { animations and simulations, practice } \\
\text { questions and quizzes. The } \\
\text { developed media has been validated } \\
\text { by media experts using an } \\
\text { instrument in the form of a } \\
\text { questionnaire. Also, it worthy of } \\
\text { being used as a medium } \\
\text { learning in middle school }\end{array}$ \\
\hline 4 & $\begin{array}{l}\text { Apriani \& } \\
\text { Broto, 2017) }\end{array}$ & $\begin{array}{l}\text { Development of } \\
\text { Android } \\
\text { Applications in the }\end{array}$ & $\begin{array}{l}\text { (R\&D)Develo } \\
\text { pment }\end{array}$ & $\begin{array}{l}\text { Physics workbook that has been } \\
\text { developed already } \\
\text { qualified as a learning media to }\end{array}$ \\
\hline
\end{tabular}




\begin{tabular}{|c|c|c|c|c|}
\hline & & $\begin{array}{lr}\text { Form of } & \text { Moodle- } \\
\text { Based } & \text { Physics } \\
\text { Workbooks } & \text { to } \\
\text { Support rrabile } \\
\text { Learning for } & \text { High } \\
\text { School Students. }\end{array}$ & & $\begin{array}{l}\text { support mobile learning for high } \\
\text { school students. Media } \\
\text { Mobile learning learning using } \\
\text { Moodle software can be accessed } \\
\text { online via mobile learning media. }\end{array}$ \\
\hline 5 & $\begin{array}{l}\text { (Astuti et al., } \\
\text { 2017) }\end{array}$ & $\begin{array}{l}\text { Physics Learning } \\
\text { Media Development } \\
\text { Media } \\
\text { Mobile Learning } \\
\text { Android based }\end{array}$ & $\begin{array}{l}\text { Development } \\
\text { (R\&D) with } \\
\text { ADDIE } \\
\text { development } \\
\text { model }\end{array}$ & $\begin{array}{l}\text { The Android-based mobile learning } \\
\text { media application is already valid } \\
\text { for use in } \\
\text { physics learning }\end{array}$ \\
\hline 6 & $\begin{array}{ll}\text { (Gagese } & \text { et } \\
\text { al., 2018) }\end{array}$ & \begin{tabular}{|lr|}
\multicolumn{3}{|l|}{ Android-Based } \\
Mobile Learning \\
Development on \\
Dynamic & Electrical \\
Materials & \\
\end{tabular} & $\begin{array}{l}\text { ADDIE } \\
\text { development } \\
\text { model }\end{array}$ & $\begin{array}{l}\text { Android-based mobile learning } \\
\text { program that was developed can be } \\
\text { used as a learning medium for } \\
\text { students }\end{array}$ \\
\hline 7 & $\begin{array}{l}\text { (Khumaidi \& } \\
\text { Sucahyo, } \\
\text { 2018) }\end{array}$ & $\begin{array}{l}\text { Development of a } \\
\text { Physics Mobile } \\
\text { Pocket Book as an } \\
\text { Android-Based } \\
\text { Learning Media on } \\
\text { Momentum and } \\
\text { Impulse Materials }\end{array}$ & ADDIE & $\begin{array}{l}\text { In general, the developed Physics } \\
\text { mobile pocket book media is } \\
\text { suitable for use as a medium for } \\
\text { learning Physics on Momentum and } \\
\text { Impulse material }\end{array}$ \\
\hline 8 & $\begin{array}{l}\text { (Taufik \& } \\
\text { Kristanto, } \\
\text { 2018) } \\
\\
\end{array}$ & \begin{tabular}{|l} 
Development of \\
Mobile Learning \\
Based on Android \\
Applications \\
Subjects Physics \\
Subject Pirect \\
Current Electricity \\
in XI Class SMK \\
Negeri 2 Kediri \\
\end{tabular} & $\begin{array}{l}\text { R\&D } \\
\text { development } \\
\text { model } \\
\end{array}$ & $\begin{array}{l}\text { the development of mobile learning } \\
\text { based on Android applications for } \\
\text { physics subjects, direct current } \\
\text { electricity is effectively used in XI } \\
\text { class learning activities at SMK } \\
\text { Negeri } 2 \text { Kediri }\end{array}$ \\
\hline 9 & $\begin{array}{l}\text { (Saraswati, } \\
\text { 2019) }\end{array}$ & $\begin{array}{l}\text { Feasibility of } \\
\text { Mobile learning } \\
\text { Media on Core } \\
\text { Physics Materials } \\
\text { Radioactivity }\end{array}$ & $\begin{array}{l}\text { R\&D } \\
\text { development }\end{array}$ & $\begin{array}{l}\text { physics learning media, based on } \\
\text { android application on the subject of } \\
\text { core physics and radioactivity has an } \\
\text { average value of } 85.71 \% \text { with a very } \\
\text { good interpretation. Thus, this } \\
\text { product can be tested in the field for } \\
\text { users to obtain products that are } \\
\text { suitable for use as alternative } \\
\text { learning media in the classroom }\end{array}$ \\
\hline 10 & $\begin{array}{l}\text { (Tisarna, } \\
\text { 2019) }\end{array}$ & $\begin{array}{lr}\text { The Influence of } \\
\text { Discovery } & \text { Learning } \\
\text { Model } & \text { Through } \\
\text { Digital } & \text { Literacy } \\
\text { Strategy on } & \text { Student } \\
\text { Physics } & \text { Learning } \\
\text { Results }\end{array}$ & $\begin{array}{l}\text { Quasi } \\
\text { experiment }\end{array}$ & $\begin{array}{l}\text { discovery learning models through } \\
\text { digital literacy strategies have a } \\
\text { significant influence in improving } \\
\text { students' physics learning outcomes } \\
\text { compared to discovery learning } \\
\text { models }\end{array}$ \\
\hline
\end{tabular}




\begin{tabular}{|c|c|c|c|c|}
\hline 11 & $\begin{array}{l}\text { (Sumarsono } \\
\& \text { Sugiyanto, } \\
\text { 2019) }\end{array}$ & $\begin{array}{l}\text { Development of } \\
\text { Android-Based } \\
\text { Mobile learning for } \\
\text { Transistor } \\
\text { Application } \\
\text { Practicum }\end{array}$ & $\begin{array}{l}\text { ADDIE } \\
\text { development } \\
\text { model }\end{array}$ & $\begin{array}{l}\text { The results of the learning media } \\
\text { feasibility test as a whole obtained a } \\
\text { percentage value of } 91 \% \text {. Based on } \\
\text { these results, this learning medium is } \\
\text { very well used as a learning } \\
\text { supplement on transistor application } \\
\text { practices }\end{array}$ \\
\hline 12 & $\begin{array}{l}\text { (Somantri, } \\
\text { 2019) }\end{array}$ & $\begin{array}{l}\text { Utilization } \\
\text { WhatsApp as an } \\
\text { Effort to Improve } \\
\text { Student Learning } \\
\text { Outcomes } \\
\text { Physics Subjects }\end{array}$ & $\begin{array}{l}\text { learning } \\
\text { models } \\
\text { include } \\
\text { discovery } \\
\text { learning, } \\
\text { problem based } \\
\text { learning, and } \\
\text { project based } \\
\text { learning }\end{array}$ & $\begin{array}{l}\text { there is an improvement in learning } \\
\text { outcomes in each cycle. The } \\
\text { learning results of students in cycle } \\
\text { III reach above the minimum } \\
\text { completion criteria (Minimum } \\
\text { Completeness Criteria) so that it can } \\
\text { be concluded that whatsApp } \\
\text { application can be used to improve } \\
\text { the learning outcomes of students in } \\
\text { class X TBSM SMKN } 4 \\
\text { Tasikmalaya in the first semester of } \\
\text { the 2018/2019 school year }\end{array}$ \\
\hline 13 & $\begin{array}{l}\text { (Sulaiman et } \\
\text { al., 2020) }\end{array}$ & $\begin{array}{l}\text { Development of } \\
\text { Physics-Based } \\
\text { Interactive } \\
\text { Multimedia Mobile } \\
\text { learning Use of } \\
\text { Website Builder. }\end{array}$ & DDDE Model & $\begin{array}{l}\text { through the stages of planning, } \\
\text { designing, developing and } \\
\text { evaluating interactive multimedia } \\
\text { based on mobile learning physics is } \\
\text { developed to be valid, effective, and } \\
\text { practical }\end{array}$ \\
\hline
\end{tabular}

The product reviewed is a mobile learning-based learning media that is applied to learning activities in the classroom and outside the classroom. This learning media is expected to facilitate educators (teacher) and students in doing learning. Students are expected to be able to study independently anywhere and anytime so that they can improve their critical thinking skills (Purnama et al., 2017). So that the learning media developed can be run in accordance with its usefulness.

Learning media has a very important role in achieving the objectives of learning. This is because the media is a tool used to convey the content of learning. (Daryanto, 2010) states that the use of learning media can overcome the limitations of space, time, energy and senses, besides that learning media can create a passion for learning. The development of learning media is needed to be able to overcome problems in the learning process, one form of developing learning media is the use of information and communication technology (ICT).

This learning media is remembered for learning media classes that depend on portable learning. This is in accordance with the meaning of multi-purpose learning expressed by (O'Malley et al., 2003)to specifically find that (students) do not just stay in one place or learning exercises that occur when students use portable innovation gadgets. Most students use smartphones every day. There are smartphones on the market that are very popular, namely Apple and Android.

Smartphones that are becoming a trend today and the development is very rapid is Android, so the development of mobile learning in Android is very promising. The use of mobile learning media is very helpful in the delivery of lesson materials. The material taught in schools is very much and the time allocation given in the learning process at school is very limited. This limited time allocation causes teachers to sometimes only prioritize the 
completion of subject matter and give students less opportunity to practice working on questions.

The lack of students in practicing questions can result in the inability of the material and concepts to be less than optimal. Mobile devices used in mobile learning include: mobile phones/smartphones, laptops, and PC. The characteristics of this mobile device have a very high level of flexibility and portability so that it can allow students to be able to access materials, instructions and information related to learning anytime and anywhere they are. The use of cellphones in the field of education in Indonesia, especially for independent learning of students is still very little used, even though every day students cannot be separated from cellphones.

The development of mobile learning media can be one of the alternative self-learning media that is more interesting, easier, more efficient and can be used by users / learners to learn wherever and whenever needed. One of the considerations in developing mobile phones into mobile learning media is the basis of the operating system used. The operating system is a link between the application and the hardware so that the user can perform certain functions.

The operating system on the mobile phone used by students in the school is based on android, the rest is Iphone etc. Android is a satisfying mobile framework. Android frameworks that support the advancement of apps and tools convey limits on tools that make use of the Android framework relied on to create versatile learning media delegation. The resulting media is not only monotonous with text, but also contains audio/visual multimedia elements and even animations that make it easier for students to understand the material.

The learning media created has some interesting and detrimental things. A great learning medium is created, which can work on gadgets that depend on Android and Windows; introduce separation materials in three-dimensional space in an interesting and direct way; presents examples of problems that fluctuate with changes in the degree of the problem; Material introductions are complemented by images and activities to help students understand the material. In addition to the favorable circumstances referred to earlier, learning media also suffers from deficiencies. The weaknesses of mobile learning learning media include not being able to operate on mobile devices with operating systems other than Android, media interactivity is still lacking, it will be left behind if the system is not updated regularly.

The benefits of using mobile learning as for the function or benefits of mobile learning in learning is as stated by (Nugroho, 2014) there are three main functions of using mobile learning as: (1) Mobile learning as a supplement can be interpreted that there is freedom for students to choose and utilize mobile in accessing learning materials or in their use as a learning medium. (2) Mobile learning can be said to be complementary because it can be used as an evaluation tool, enrichment and, reinforcement and can be used to recall the learning that has been done even without the help and assistance of teachers or tutors. (3) Mobile learning as a substitute may imply that students may be given the opportunity to choose the ideal learning model.

The benefits of using mobile in learning as presented by (Woodille, 2011) The main advantages in the use of mobile devices in learning can be described as follows: First, Portability. Second, anytime and connect anywhere. Third, Flexible access and precise access to e-learning resources. Fourth, fast communication. Fifth, Empowerment and involvement of learners, especially those in the wider community. Six, active learning experience.

Versatile learning can encourage simple students to give their all more transparency when they are in class. Educators can also use mobile phones to communicate with students who need extraordinary consideration. The consequence of research in creating versatile 
learning apps is learning media application items and elective learning assets that can be run on phones with the Android framework. The position of the application in learning is as a supplement. The supplement in question is a learning support where the time and place of use does not have to be in the classroom but can be outside of learning hours. The application as a supplement is intended so that students can play and study independently in their spare time, considering that learning time at school is very limited.

This understanding is in line with that proposed by mobile learning, which can be used by educators to deliver learning materials flexibly anywhere and anytime. Meanwhile(Conway III, 2013) defines Mobile learning as a type of learning that provides educational content and learning support materials through wireless communication devices. This m-learning framework uses the portability of mobile phones, for example, mobile phones and PDAs, to provide learning capacity that should be possible anywhere and anytime. Versatile learning cannot replace traditional classes but can be used as a complement to learning procedures in classrooms and universities.

Meanwhile (Handayani \& Suharyanto, 2016) carry out development (R\&D) with a 4-D model, namely define, design, develop, and disseminate. The define stage is carried out by analyzing the problems contained in physics learning. The design stage is carried out by making the initial design of the mobile-learning application and research instrument. The develop stage is carried out to produce a decent mobile learning application and to describe the improvement of learning outcomes and learning motivation of students. The overall value of the pretest he did, showed that it was higher than the posttest score. This shows that students' physics learning outcomes increase after using Android-based mobile learning. The use of mobile learning is an advantage in learning activities.

Efforts to improve the learning outcomes of learners can also be done through the use of WhatsApp such as research conducted by (Somantri, 2019). This study uses Class Action Research (PTK) with teachers as researchers as well as educators in the class. The research was conducted in the classroom. The data showed that the use of WhatsApp (WA) application can improve the learning outcomes of students. Students are becoming more active in learning because they often access information in WhatsApp. Learning can be done anywhere and anytime not limited by space and time. The remedial improvement process can also be carried out anytime and anywhere so that it does not interfere with the process or reduce the allocation of learning time. All students experienced an increase in their learning outcomes in terms of attitudes, knowledge, and skills. Based on the questionnaire, it shows that all students agree that the use of WhatsApp can improve student learning outcomes.

Based on the results of the literature review conducted showed that the development of mobile learning media can improve digital literacy and student learning outcomes in physics subjects. This learning medium has the advantage, that students can access the lesson materials from anywhere without being limited by space and place and have flexibility, because it is not related to time. Although the researchers used the R\&D approach model, there are several different models namely ADDIE, DDDE, 4D, and Quasi Experiments. Each model has its advantages and disadvantages, including:

\subsection{Addie}

There is one learning design model that is more generic, namely the ADDIE (AnalysisDesign-Develop-Implement-Evaluate) model. ADDIE appeared in the 1990s developed by Reiser and Mollenda. The model was developed by Mollenda and Reiser (2003). This model is often used to describe a systematic approach to instructional development. In addition, Molenda also said that the ADDIE model is a general learning model and suitable for development research. When used in development, this process is considered sequential but 
also interactive (Molenda,2003). In line with Molenda's opinion, Cheung (2016:4) states that ADDIE is an easy-to-use model that can be applied in a curriculum that teaches knowledge, skills or attitudes.

1) The Advantages of ADDIE Model

a) This model is simple and easy to learn. These five stages / steps are very simple when compared to other design models. So that it can be easily learned by instructors / educators.

b) The structure is systematic, as we know that the ADDIE model consists of 5 components that are interrelated and structured systematically, which means that from the first stage to the fifth stage in its application it must be systematic, it cannot be sorted randomly or chosen which one we like to come first. Because these five stages / steps are very simple when compared to other design models. Because of its simple nature and systematically structured, this design model will be easy to learn by educators.

2) The Disadvantages of the ADDIE Model

The analysis stage takes a long time. In this analysis stage, the designer/educator is expected to be able to analyze the two components of the students first by dividing the analysis into two, namely performance analysis and needs analysis. The two components of this analysis will affect the length of the process of analyzing students before the learning stage is carried out. These two components are important because they will affect the next stage of learning design.

\subsection{D (Define, Design, Develop, and Disseminate)}

1) The Advantages of $4 \mathrm{D}$ models

a) It is more appropriate to use it as a basis for developing learning tools not for developing learning systems,

b) The description looks more complete and systematic,

c) In its development involves expert judgment, so that, so that before the trials in the field of learning devices have been revised based on the assessment, suggestions and critics of experts.

\subsection{The Disadvantages of 4D Models}

However, in this 4D model there are also disadvantages, such as there is no clarity which should take precedence between concept analysis and task analysis.

\subsection{Quasi Experiments}

This form of experimental design is a development of true experimental design, which is difficult to implement. This design has a control group, but it cannot function fully to control the external variables that affect the implementation of the experiment. However, this design is better than the pre-experimental design. Quasi Experimental Design is used because in reality it is difficult to find a control group used for research.

1. The Advantages

Quasi Experimental Research In this pseudo-experiment study does not have strict limits on randomization and at the same time can control the threats of validity.

2. The Disadvantages

a. There is no randomization, which means that the grouping of sample members in the experimental group and the control group is not done randomly.

b. Control of the variables that affect the experiment is not carried out, because these experiments are usually carried out in the community. 
Based on the description in the results of the study above, it can be said that the use of mobile learning in student learning can be used as a learning support tool, media and learning resource and can be applied at the student level. The benefit of using mobile learning in learning is that it can facilitate the teaching and learning process both in the classroom and outside the classroom, attract students' attention and can generate enthusiasm and motivation in learning so that the material being delivered can be conveyed properly and can be understood by students, besides that, another benefit of using mobile learning is that it can support students towards independent learning.

The development of mobile learning as a learning medium has been carried out by several researchers, who develop mobile learning. The results of the development carried out indicate that the media developed is more likely to focus on the teaching material. Mobile learning developed is focused as a means of practicing working on questions that can provide various types of varied and challenging questions.

The results of this study conclude that students feel more happy and motivated with all activities carried out during the learning process using the inquiry model compared to the learning process commonly applied in schools so far and can improve critical thinking skills and get a positive response from students. Inquiry learning can have a positive impact on the activities, attitudes and performance of students and effective inquiry learning to improve mastery of concepts and develop the character of students.

The product resulting from this development research is a mobile-based learning media application. This learning media product was created and designed by the researcher himself, with the aim of being able to be used as a teacher's tool in delivering material and also as an independent learning resource that students can use at any time. In the process of designing this android-based media there are suggestions for improvement from the validator such as containing material aspects. In addition, the images used in android-based media must be of high quality to make them appear clearly. Selection of high quality images will make students happy and enthusiastic in learning activities. In this case, m-learning-based learning media can be used as learning media for students because the average feasibility value shows that the application is feasible, students can study substances and their characteristics, such as elements, compounds, and mixtures by using this application on their smartphones. In addition, students can also evaluate their knowledge by following the quiz section on the developed android media.

\section{Conclusion}

Based on the results of this study, it is hoped that it can be a consideration for teachers to apply m-learning in physics lessons so that the teaching and learning process can be more effective and can support students in learning that will have an impact with student learning outcomes.

From the conclusion above, teachers are advised: 1) to use various learning media in teaching, 2) to use mobile learning media on essential materials related to national exams, so that students can see and remember quickly at any time because usually the cell phone is always carried, 3) mobile learning can also be used as an enrichment material for students who are fast or for the remedial students who are slow to reach the Minimum Completeness Criteria, 4) this mobile learning, has limitations in the question of multiple choice, option only three. Therefore, the next researcher can develop a different program that has a minimum choice of 5 in accordance with the requirements of student level evaluation questions. 


\section{References}

Apriani, V., \& Broto, W. (2017). Pengembangan Aplikasi Android Berupa Workbook Fisika Berbasis Moodle Sebagai Pendukung Mobile learning Untuk Siswa Sma. Prosiding Seminar Nasional Fisika (E-Journal), 6, SNF2017-RND.

Astuti, I. A. D., \& Bhakti, Y. B. (2018). Interactive learning multimedia based Microsoft excel on the temperature and heat. Unnes Science Education Journal, 7(1).

Astuti, I. A. D., Sumarni, R. A., \& Saraswati, D. L. (2017). Pengembangan media pembelajaran fisika mobile learning berbasis android. Jurnal Penelitian \& Pengembangan Pendidikan Fisika, 3(1), 57-62.

Aziziyah, D. A. (2019). Perbedaan Hasil Belajar Antara Menggunakan Media Pembelajaran Berbasis Android Dengan Power Point Interaktif Pada Pembelajaran Fisika Kelas X Di Smk Negeri 4 Semarang. Universitas Negeri Semarang.

Chaeruman, U. A. (2010). E-learning dalam pendidikan jarak jauh. Jakarta: Kemendiknas.

Conway III, L. G. (2013). Development of Mobile learning Using Android Platform. International Journal of Information Technology \& Computer Science (IJITCS), 9.

Daryanto. (2010). Media Pembelajaran. Yogyakarta: Penerbit Gava Media.

Fatimah, S. (2014). Pengembangan Media Pembelajaran IPA-Fisika Smartphone Berbasis Android Sebagai Penguat Karakter Sains Siswa. Jurnal Kaunia, X No. 1, A(April 2014/1435: ISSN 1829-5266), 59-64.

Gagese, N., Wahyono, U., \& Kendek, Y. (2018). Pengembangan Mobile learning Berbasis Android pada Materi Listrik Dinamis. JPFT (Jurnal Pendidikan Fisika Tadulako Online), 6(1), 44-49.

Gunawan, I. (2014). Pengembangan Aplikasi Mobile learning Fisika Sebagai Media Pembelajaran Pendukung. Jurnal Ilmiah Pendidikan Fisika Al-Biruni, 3(1), 20-26.

Handayani, T. S., \& Suharyanto, S. (2016). Pengembangan Mobile learning Berbasis Android Sebagai Media Pembelajaran Pada Materi Fluida Statis Untuk Meningkatkan Minat Dan Hasil Belajar Ranah Kognitif Peserta Didik. E-Journal Pendidikan Fisika, 5(6), 384-389.

Hartawan, I. K. A., Tastra, I. D. K., \& Pudjawan, K. (2014). Pengembangan portal e-learning berbasis moodle pada mata pelajaran fisika kelas x di sma dwijendra denpasar. Jurnal Edutech Undiksha, 2(1).

Hartini, S., Susilowati, E., \& Misbah, M. (2019). Media pembelajaran fisika SMA berbasis elearning di Kabupaten Tanah Laut sebagai upaya melatihkan literasi digital. PRO SEJAHTERA (Prosiding Seminar Nasional Pengabdian Kepada Masyarakat), 1(1).

Jamilah, P. N., Mulyaningsih, N. N., \& Bhakti, Y. B. (2020). The Effect of Learning Start Learning Strategy With A Question (LSQ) on the Mastery of Physics Concepts. Bulletin of Educational Science and Technology, 1(1), 20-26.

Karsidi, R. (2017). Budaya lokal dalam liberalisasi pendidikan. The Journal of Society and Media, 1(2), 19-34.

Khumaidi, A., \& Sucahyo, I. (2018). Pengembangan mobile pocket book fisika sebagai media pembelajaran berbasis android pada materi momentum dan impuls. Inovasi Pendidikan Fisika, 7(2).

Nugroho, S. (2014). Pemanfaatan Mobile learning Game Barisan dan Deret Geometri untuk Meningkatkan Minat dan Hasil Belajar Matematika SMA Kesatrian 1 Semarang. Indonesian Digital Journal of Mathematics and Education, 1(1), 1-7.

O’Malley, C., V., G., G., J. P., T., J., S., \& Lefrere, P. (2003). Guidelines for learning/teaching/tutoring in a mobile environment. 
Paramita, A. P., Siahaan, B. Z., \& Astra, I. M. (2017). Pengembangan Media Pembelajaran Berbentuk Animasi Berbasis Mobile learning (M-Learning) Pada Materi Gerak Lurus Di Smp. Prosiding Seminar Nasional Fisika (E-Journal), 6, SNF2017-RND.

Pradana, D. et al. (2020). Nasionalism: Character Education Orientation in Learning Development. Budapest International Research and Critics Institute-Journal (BIRCIJournal). P. 4026-4034.

Purnama, R. B., Sesunan, F., \& Ertikanto, C. (2017). Pengembangan media pembelajaran mobile learning berbasis android sebagai suplemen pembelajaran fisika SMA pada materi usaha dan energi. Jurnal Pembelajaran Fisika, 5(4).

Saraswati, D. L. (2019). Kelayakan Mobile learning Media pada Materi Fisika Inti dan Radioaktivitas. Journal of Teaching and Learning Physics, 4(2), 25-34.

Somantri, S. (2019). Pemanfaatan Whatsapp sebagai Upaya Meningkatkan Hasil Belajar Peserta Didik pada Mata Pelajaran Fisika. UPEJ Unnes Physics Education Journal, 8(1), 28-33.

Suarsana, I. M. (2013). Pengembangan e-modul berorientasi pemecahan masalah untuk meningkatkan keterampilan berpikir kritis mahasiswa. JPI (Jurnal Pendidikan Indonesia), 2(2).

Sudarsana, I. K. (2016). Pemikiran tokoh pendidikan dalam buku lifelong learning: policies, practices, and programs (Perspektif Peningkatan Mutu Pendidikan di Indonesia). Jurnal Penjaminan Mutu, 2(2), 44-53.

Sulaiman, U., Djafar, A. F., \& Ali, Z. (2020). Pengembangan Multimedia Interaktif Fisika Berbasis Mobile learning Penggunaan Website Builder. Jurnal Pendidikan Fisika, 8(2), 92-98.

Sumarsono, W., \& Sugiyanto, S. (2019). Pengembangan Mobile learning Berbasis Android untuk Praktikum Aplikasi Transistor. UPEJ Unnes Physics Education Journal, 8(3), 262-271.

Taufik, M., \& Kristanto, A. (2018). Pengembangan Mobile learning Berbasis Aplikasi Android Mata Pelajaran Fisika Materi Listrik Arus Searah Kelas XI SMK Negeri 2 Kediri. Jurnal Mahasiswa Teknologi Pendidikan, 9(2).

Tisarna, A. (2019). Pengaruh Model Discovery Learning Melalui Strategi Literasi Digital Terhadap Hasil Belajar Fisika Peserta Didik. UIN Raden Intan Lampung.

Wahyudi, A. (2015). Indonesia, Raksasa Teknologi Digital Asia. http://katadata.co.id/opini/2015/09/29/indonesia-raksasa-teknologi-digitalasia\#sthash.hmXDpXjY.dpbs

Woodille, G. (2011). Mobile Learning. US: The Mc Graww- Hill Companies. 